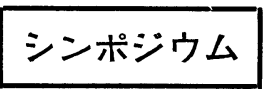

\title{
深在性真菌症の免疫学的診断の研究
}

\author{
アスペルギルス症とクリプトコックス症について
}

秋 葉 朝 一 郎

東京大学医学部細菌学教室

深在性真菌症が藥椷療法, 理学療法の発達に伴う一面 として近年増加しつ〉あるととは世界的傾向とされてい るが，吾國に掠いても同様であり，カンジダ症とアスペ ルギルス症とは特に近年多くなつてきた点に扔いて注目 されね㤝なない疾患である。これに比べるとクリプト コックス症は症例はすくなくないが, 慢性の経過をとり 多くの慢性疾患との鑑別学必要とする点化捛いて注目す べき真菌症といわね涪ならない。

深在性カンジタ症については免疫反隹が，功り信頼 すべき診断法であるという所見吾吾从はすでに報告し $\digamma^{1 / 2)}$.

今包は, カンジダ症についで重要と思われるアスペル ギルス症とクリプトコックス症に対する免疫学的診断法 に関する余らの基礎的研究の成績について報告したい.

\section{I. アスペルギルス症の免疫学的診断}

Aspergillus sp は自然界に廣く存在し, 植物, 昆虫, 鳥, 家畜などに対して病原性をもつといわれるが，人の 疾病々関連の最も深い種は Aspergillus fumigatus であ り, このほが A. flavus, A. nidulans, A. glaucus なざ に因る感染むあるといわれる。

アスペルギルス症には, 外耳道, 皮僦, 爪, 副鼻腔,

眼, 腟などの表在感染症が多いが, 気管支や肺などの深 在性感染も決して稀なむのではない.

気管支・肺アスペルギルス症の拣とんどすべてが $A$. fumigatus によつてひきおこされるといわれている.

肺アスペルギルス症の真菌学的診断は, 痰中に菌糺 (hyphal fragments) や胞子を認めることと菌の培盖 檢出とが現在一般注こなわれているが, とのような方

Tomoichiro AKIBA: Serologic diagnosis of the deep-seated mycosis. Department of Bacteriology, Faculty of Medicine, University of Tokyo. -Japan. J. Med. Mycol., 1, 1960.
法で診断がつかず切除肺又は死後の剖檢によつてはじめ て診断される場合がすくなくない。

な扮痰よりの培養檢出の價值であるが, Aspergillus は 実驗室内の雜菌として日常遭遇するものであるの及なら ず, 痰のごときものから腐生的存在として檢出されるも のである.とくに喘息, 慢性気管支炎, 気管支擴張症, 肺結核, 癌などの患者の痰からはしばしば檢出されると いわれている。

從つて, 痰のごとき檢体から Aspergillus が反復して 培養されたとしても, この所見加たざちに感染を復て していると診断することは伦險であろう。

上述のような理由から, 深在性アスペルギルス症に対 しては免疫学的診断法が必要であると考えられるわけで ある.

多くの医真菌学の成害には, アスペルギルス症の免疫 学診断は研究が進んでいないので, 不明であると記載さ れているが, しかし数種の交献学見出すことができる.

Drake $^{3)}$ (1948) は A. nidurans の菌体磨碎液によつ て感染ウサギにツベルクリン型の皮内反應が陽性となる とと老報告し, Stanley ${ }^{4}$ (1950) は A. fumgatus 菌 体抽出多糖体分劃学用いて感染ウサギについて皮内反隹 定試及菌接種後 5 日頃より反應陽轉すると報告した。川 上・大久保ら ${ }^{5)}$ (1957) は, 肺アスペルギルス症の 1 例 に扮いて，A.fumigatus 培養滤夜を抗原として皮内反 應を試反，陽性であつたものが手術によつて感染病巢を 除去した液には乗内反應が陰性化した例定報告した。

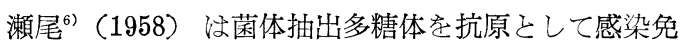
疫ウサギについて皮内反應と感作血球凝集反應安抗こな い反㣹陽性となるとと学報告した。

沈降反應に関しては, Henrici ${ }^{7}$ (1939) が A. fumigatus の菌体磨碎液を抗原として免疫ウサギについて检 討し, 反應陽性を呈するこを報告している. 
以上の交献にてらして深在性アスペルギルス症におけ る免疫学的診断の可能性が推測できるのであるが, 余ら の研究成績もまたてれを支持するものであつた。だ゙こ の場合重要な問題は抗原のつくりかたである. 吾々は大 久保の報告例飞試及て, 皮葴反㗹有効な抗原が培盖滤 液中に含まれていることを知つたのであるが, 抗原抽出 の能率を考え, また Henrici の報告參考として, ま づ菌体磨碎液を抗原として用いる方法を检討した。

\section{1） A. fumigatus $の$ 菌体磨砕液抗原}

A. fumigatus 村松株（肺アスペルギルス症分離株） のサブローブイヨン培地10１4日培養液の菌体を集めて 細切し, これに 4 倍量の生理食塩水を加えて滅菌海砂を 用いて磨碎し, 遠沈した上清定ザイツ濾過器によつて濾 過したものを抗原の原液とした。

A. fumigatus の胞子浮游液 ( $0.5 \% \mathrm{CMC}$ 加生食水) を腹腔内に接種したウサギについて, 皮内反應と沈降反 應 (抗原稀釋, 重層法) 定試みた. 感染20日後より兩反 應とも陽性となり, 沈降價の最高は抗原 40 倍稀釋まで 陽性となり, 皮内反應も5〜10倍稀釋まで陽性となつた が, 感染の治痖経過とともに減弱していつた。

以上のごとき所見を得た折に, 國鉄中央病院の呼吸器 科に入院中の患者で, 肺結核に併発した肺アスペルギル ス症(気管支擴張性アスペルギローム) 1 例 上記抗原を用いて免疫反應を試及る機会を得た。 その結 果は圖 1 に示した。

患者吉沢某 (26才, 男) は肺結核の治療実施中, 右肺 鎖骨上野に空洞が発見されて手術のため國鉄中央病院に 入院した (32年10月). 当時結核菌は鏡檢, 培養ともに陰 性. 同年12月 3 日区域切除学括てなつたが, 術後気管支

図 1 Aspergillus fumigatus 磨砕抽出抗原に よる肺アスペルギルス症患者（吉沢）の 皮内反応並びに沈降反応の消長

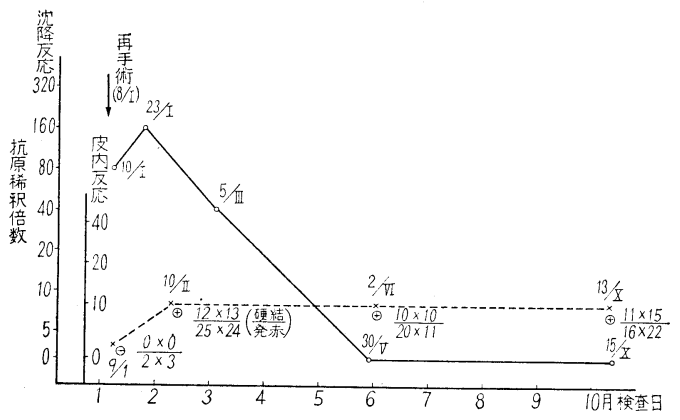

㾯をつくり無気肺となつたので，33年 1 月 8 日再手術を 受けた。 そのとき前包手術の肺区域制離面にアスペルギ ルスの感染巣を発見した. よつて右上葉の切除を行つて 全治した例であるが，前記の空洞は Aspergillom であ つた.

この症例では，皮内反應は抗原10倍稀程液を以て，手 術後 3 日から 10ケ月にいたるまで発赤11〜16 $\times 20 〜 22$ $\mathrm{mm}$, 硬結 $10 \times 15 \mathrm{~mm}$ であつた. 但し健康人ではこの濃度 で，小発赤を認めるのみで硬結はなかつた。

沈降反應は, 手術後 2〜 5 日棌取した血清では抗原 160倍稀䆁まで陽性であつたが，2 月月後には低下して 40倍まで陽性となり5ケ月経過後には陰性となつた。

即与, 血清抗体注病巢除去後梳わりあい速やか飞減少 するが，皮内反雇はかなり持続するもののようである.

以上 2 例の肺アスペルギルス症の経驗から, 深在性ア スペルギルス症の免疫学的診断が可能であるとの示唆を 得たが, 培盖滤液や菌体磨碎液学抗原と亓る場合は抗原 の含量や活性の測定が不正確となる久点があるので, 安 定した抗原を分離することを次のテーマとした。

\section{2) A. fumigatus $の$ 多糖体抗原}

多糖体分劃のとりかたは先に報告したカンジダの場合 と同様である.ブドウ糖サブローブィヨンに胞子を接種 し, $37^{\circ} て ゙ 4 〜 5$ 日間振蕰培養学行なつた村松株の菌体を あつめ洗桬した後ホモジナイザーにかける.ついで90〜 $95 \%$ 石炭酸 3 倍量を加えて $2 \sim 3$ 日放置後遠沈し, 沈渣 をエタノールで洗つて石炭酸を除く.ついで沈椬に適量 の水を加え, $100^{\circ} 60$ 分間の加熱抽出を捛こなう. 上清を 透析後シャンベラン滤過器にて滤過し, 濾液を濃縮して から 3 倍量のエタノールと醀酸ソーダを加え一夜永室に 放置して, 析出する沈溉娄取り, アセトンで洗つて乾燥 する．この多糖体分劃の生理食塭水溶液を抗原として使 用した.

A. fumigatus 村松株, 久保山株, 吉沢株 (いづれも 肺アスペルギルス症より分離したもの) 及びA. niger \# 16(空中より分離したもの), Penicillium notatum \#2381 を用い, その胞子浮游液鼻腔内滴下して感染させた ウサギについて, 感染経過を追うて皮内反應及び沈降反 憵を試みた。

A. fnmigatus 経鼻感染ウサギに抢いては肺に結節様 病巢乃至空洞が認められ, また気管支と肺胞壁における 菌糸の增殖, 組織内えの侵入, 肺組織の壊死融解の像が 認められた. A. fumigatus 感染ウサギに抢ける抗体産 生の消長を見るに，鼻腔内接種開始後10日頃より免疫 
図 2 A. fumigatus 久保山株鼻腔内接種 ウサギ (No. 39) に打ける抗体の消 長 (多糖体抗原)

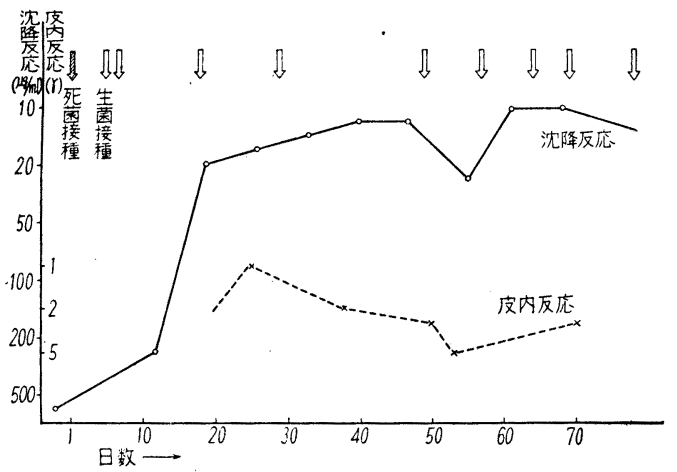

反應が陽轉し 20〜30日後には最高值に達し（沈降反應10 〜20 r/cc陽性, 皮内反應 $1 \gamma$ 陽性), 生存例に沶いては 60〜70日以上もひきつ今゙き反應陽性であつた（圖2，3）。
因 3 A. fumigatus 吉沢株鼻腔内接種 ウ サギ(No.42) に打ける抗体の消長 (多糖体抗原)

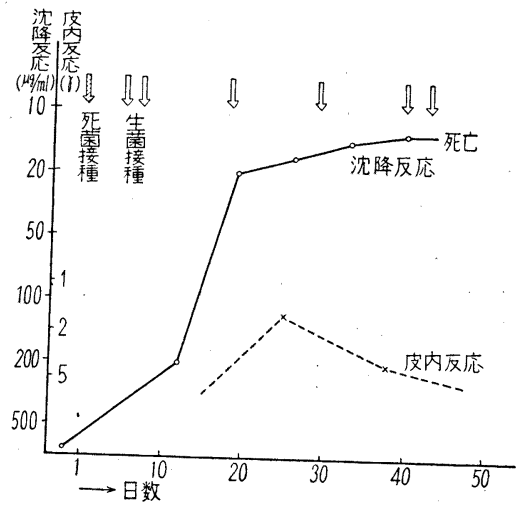

死亡は，接種後40〜50日頃に拉きる例が多かつたが，死 の直前には皮内反應の低下する例が見られた。

- 表 1 Aspergillus sp. 感染ウサギに捪ける免疫反応（多糖体抗原）

\begin{tabular}{|c|c|c|c|c|c|c|}
\hline \multirow{2}{*}{ ウサギ番号 } & \multirow{2}{*}{ 使 用菌株 } & \multirow{2}{*}{\multicolumn{2}{|c|}{ 接種法 }} & \multicolumn{2}{|c|}{ 沈降反応 $(\gamma / c c)$} & \multirow{2}{*}{ 皮内反応 $(\gamma)$} \\
\hline & & & & 前 & 後 & \\
\hline 15 & $\begin{array}{c}\text { A. fumigatus } \\
\text { 村 }\end{array}$ & 腹 & 腔 & $500(-)$ & $50(+)$ & $1(+)$ \\
\hline 40 & " & & & $500(-)$ & $50(+)$ & \\
\hline 36 & "I & & 腔 & $500(-)$ & $50(+)$ & $1(+)$ \\
\hline 38 & " & & & $500(-)$ & $20(+)$ & $1(+)$ \\
\hline 39 & 久 保 山 & & & $500(-)$ & $10(+)$ & $1(+)$ \\
\hline 45 & " & & & $500(-)$ & $10(+)$ & $1(+)$ \\
\hline 41 & 沢 & & & $500(-)$ & $20(+)$ & $2(+)$ \\
\hline 42 & " & & & $500(-)$ & $20(+)$ & $2(+)$ \\
\hline 43 & Asp. niger & & & $500(-)$ & $50(+)$ & $2(+)$ \\
\hline 44 & " & & & $500(-)$ & $20(+)$ & $2(+)$ \\
\hline 48 & Pc. notatum & & & $200(-)$ & $20(+)$ & $5(+)$ \\
\hline 49 & $"$ & & & $200(-)$ & $20(+)$ & $5(+)$ \\
\hline
\end{tabular}

以上の経過はカンジタ感染ウサギの場合に似ており， アスペルギルス感染はカンジタ感染と同様に急性の経過 をとり抗体の産生が 比較的速かであるととを示してい る.

次に抗原の特異性について見るに，表 1 亿示したごと く村松株多糖体は, 久保山株, 吉沢株感染ウサギに招い ても村松株感染と同程度に強い反應を示した.

な打村松株多糖体は, A. niger 感染ウサギのみなら ず, Penicillium notatum 感染ウサギに抢いてもかなり
強い交不應を示した。

從つて本抗原による反應は Aspergillosis のみならず Penicilosis に拉いても陽性に出るととが推定され，乙 の意味では特異性が敩密でないという久点をもつととに なるが，同時に深在性 Penicilliosis の診断にも利用し 得るという利点もあるであろう．本章に関する評價は和 、田の原著 ${ }^{11}$ を曑照されたい。

以上の基礎的実驗から人の深在性アスペルギルス症の 診断用抗原として利用し得るであろうという示唆を得た 
わけである・

この抗原を用いて免疫反應を試み得た臨床例は, 現在 までに僅に 2 例にすぎないが, その成績はつぎのようで ある。

2 例とも三井厚生病院入院中の患者で, 福島博士の好 意によつて行つたものである.

皮内反應は $1 \gamma$ 注射で陽性であり, 数名の非感染者群 では㓌性の添㠜陽性も見られる。乙れに反して沈 降反雇では, 非感染者群では $500 / \mathrm{ml}$ の濃度でも陰性で あつたが，2名のアスペルギルス症患者に掞いては，1 例 (アスペルギルス性膿胸) は $5 \gamma / \mathrm{ml}$ 陽性こいう高い 抗体價を, また他の1例 (気管支アスペルギルス症) で は $200 / \mathrm{ml}$ で陽性であつた. 以上の成績から皮内反應 よりは沈降反應の方が信頼度が高いものと思われるが, この点はさらに症例を多くして检討せねばならない.

\section{II クリプトコックス症の免疫学的診断}

Cryptococcus の主たる感染経路は気道からであるが, 深在性病巢をつくり, 亞急性乃至慢性の経過をとる.肺ク リプトコックス症はしばしば見られる感染であり, 肺結 核の㴽肺の真菌性感染特に Actinomycosis, Blastomycosis, Coccidiomycosis, Candidiasis などとの鑑別 が必要である、また中樞神経のクリプトコックス症は, 結核性髓膜炎, 腦炎, 腦腫癔なぞとの鑑別が必要である といわれる.

クリプトコックス症の診断には病巢材料から Cryptococcus 分離培養する方法が一般に用いられているが, 深在性感染に怙いて蛙適用儿得ない場合がすくなくない であろう.のみならず, Cryptococcus は口腔や腸管に, 腐生的に笴生している場合のあることに注意しなけれ涪 ならない. かような意味から, もし免疫学的診断が可能 であるならば，感染の有無の診断に益するととろがすく なくないと考えられる。

本症の免疫学的診断法として從来報告されている力法 と成績学まとめて見ると次のようである。

1. 皮䖉反雇 (アレルギー反應)

2. 血清抗体の檢出（凝集反應, 沈降反應, 補体結合 反應)

3. 体液中の抗原の檢出

1. 皮虞反應：Cryptococcus の培養滤夜を抗原とし て患者の皮内反應が陽性を示したという Berghausen ${ }^{9}$ (1927), Kessel \& Holtzwart ${ }^{10)}$ (1935) らの報告があ るのみである.

2. 血清抛体の檢出: Benham ${ }^{11}$ (1935), Evans ${ }^{12)}$
13) 14) $\left(1949\right.$ 1951), Neill ${ }^{1516)}(1949 \sim 1950)$ らは免疫 ウサギにおいて抗体が産生されるととを報告している. しかし一般に抗体産生が低いととがＣrsptococcus に特 徵的であつて, しかも菌株によつては全然抗体産生が見 られない場合があるという. 人のクリプトコックス症に ついて, 血清反應㟈捛てなつた例の報告は見いだすとと ができなかつた。

3. 体液中の抗原の檢出: Neil1 ${ }^{14)}$ (1951） 万は入院 後 5 週間で死亡前 1 週のをきに, Cryptococcal meningitis の 1 例から採つた脊娟遀液, 血液及び尿を材料とし てそのなかに含まれている抗原を，ウサギ抗血清による 沈降反應と補体結合反應によつて檢出を試及, 3 檢体と も陽性であつたと報告している.

以上のごとく,クリプトコックス症の免疫学的診断法 の價值については, 研究不足のため不明といわざるを得 ない.

かような考察の結果, 吾く汸クリプトコックス症の免 疫学的研究に着手したわけであり, 動物実驗の結果から は有用であろうと思われる抗原をつくり得たのである が, いまだ臨床例について実施主当機会学得ていない.

菌株の選擇: 人の梁在性感染学招こす菌種は Cryptococcus neoformans であるが, Evans ${ }^{1213)}$ に上れば免疫 学的に A, B, C, の 3 型があるという. 彼らは人の感染 症から分離した19株の C. neoformans について, 凝集 反應, 沈降反應と萊膜反應によつて分型したのである が，19株中 A 型が13株，B型は 5 株，C型は 1 株であつ た. しかも $\mathrm{A}$ 型と $\mathrm{B}$ 型の抗血清は交刃反應が強く $\mathrm{C}$ 型血 清の及が比較的特異的であつたという.わが敉室所持の 菌株は Evaus 型のどれに屬するものかは不明である が, 菌株の大多数を示めるものが $\mathrm{A}$ と B 型でありしかも 兩型冲共通抗原が多いものとす机ば，診断用抗原の作製 のためには菌株の選擇型別の点から抢こなわなくとも よいであろうと考えた. そこで所持株のうち形態的には 莁膜の大きいと己とマウス病原性が高いというととを考 慮して

抗原の抽出: Candida albicans や Aspergillus fumigatus についての実驗結果にてらして, 多糖体分劃定抗 原として使用して見るととにした。

C. neoformans の培養滤液から抗原活性学有する多糖 体が抽出できることについては, Hehre ${ }^{19)} ら$ (1949), Neill16) ら (1949), Stanley ${ }^{20)}$ (1949), Evans ${ }^{13)}$ ら (1951)，の報告がある.

余らは從来の経驗から培養濾液から取るよりは菌体办 
ら抽出する方が多糖体の收得量がよいととを知つている ので，C. neformans の場合も菌体方ら抽出分劃する方 法をとつた.

サブロー寒天培地 $37^{\circ} \mathrm{C} 5$ 日培養の菌体を集め水で 3 回 アセトンて 3 包洗涤後乾燥. 乾燥菌体に 3 倍量の 90 95 \%石炭酸を加え 3 日間浸出して菌体少ら蛋白を抽出す る.ついで濾別した菌体をェーテルで洗つて石炭酸を除 く. 菌体に水を加えて $100^{\circ} \mathrm{C} 60$ 分加熱抽出を招こなう。 紐菌滤過器による滤液を透析後濃縮し， 3 倍量のエタノ 一ルと酷酸ソーダ小量を加えて承室に一夜放置し, 析出 する沈溉を集める。これを餾水に溶解してから, Sevag 法によつて除蛋白を抢てない, 叉エタノール沈溉を抏て なつてから沈溉をアセトンで洗つて乾燥すると白色粉末 となる.これを多糖体抗原として使用した。

ウサギの感染実驗はつぎのようにして抢てなつた.ブ ドウ糖サブロー寒天斜面上 $37^{\mathrm{c}} \mathrm{C} 48$ 㭙間培養菌体を生食水 に $1 \mathrm{mg} / \mathrm{cc}$ の濃度に浮游し, 死菌接腫の場合は $60^{\circ} \mathrm{C} 30$ 分 加熱したもの $1 \mathrm{cc}$ 生菌接腫の場合はそのままの $1 \mathrm{cc} 耳$
靜脈内に注射した。，まづ死菌を 1 週 3 包づつ 8 週注射し たが抗体産生が極て低いので，ついで生菌を週 1 2 回 づつ数包接腫した.

沈降反應は抗原稀釋法により多糖体抗原, 1 〜 1000 $\gamma / \mathrm{cc}$ 溶液 $0.1 \mathrm{cc}$ を抗血清 $0.1 \mathrm{cc}$ 上に重層する方法によ つた.

皮内反隹は, 生食水 $0.1 \mathrm{cc}$ 中に多糖体 $1 \sim 10 \gamma$ が含ま れるようにして, 脱毛した腹部皮内に注射し，24時間後 の発赤の塞10 mm以上を以て陽性とした。

な扮感染ウサギ血清について一部に凝集反雇を試みた ものもある.凝集反應は，大きい萊膜をもつ菌体では難 凝集であるが，萊膜を除いた菌体を使うと凝集し易くな る.Evans ${ }^{15)}$ の方法に從つて,大きい萊膜をもつ\#2617株 の菌体を $\mathrm{N} / 5 \mathrm{HCl}$ 亿浮游して $80^{\circ} 60$ 分加熱後 $\mathrm{NaOH}$ を以

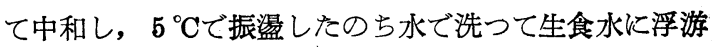
したものを抗原とした. 小さい莁膜をもつ田坂株と順天 堂株は無処置のままで抗血清によつてよく凝集された。

得た実驗成績は次のようである。

表 2 Cryptococcus neoformans 感染ウサギの免疫反応

\begin{tabular}{|c|c|c|c|c|c|c|c|}
\hline \multirow{2}{*}{ 菌 株 } & \multirow{2}{*}{ ウサギ } & \multicolumn{2}{|c|}{ 沈降反応 $(\mathrm{mcg} / \mathrm{ml})$} & \multicolumn{2}{|c|}{ 皮庿反応（mcg） } & \multirow{2}{*}{ 転 } & \multirow{2}{*}{ 剖 } \\
\hline & & 感 染 前 & 感染後 & 感染前 & 感染後 & & \\
\hline$\# 2617$ & No. 6 & $1000(-)$ & $5(+)$ & $10(-)$ & $1(+)$ & 死（10月） & 脳, 肺, 眼, 輧丸 \\
\hline$\# 2617$ & No. 7 & $1000(-)$ & $50(+)$ & $10(-)$ & $5(+)$ & 死（10月） & 脳, 肺, 臭丸 \\
\hline$\# 2617$ & No. 8 & $1000(-)$ & $50(+)$ & $10(-)$ & $1(+)$ & 死（4.5月） & 脳, 肺, 眼 \\
\hline$\# 2575$ & No. 9 & $1000(-)$ & $5(+)$ & $10(-)$ & $1(+)$ & 生 & \\
\hline$\# 2575$ & No. 10 & $1000(-)$ & $10(+)$ & $10(-)$ & $1(+)$ & 死（8月） & 脳, 肺 \\
\hline$\# 2575$ & No. 11 & $10.00(-)$ & $5(+)$ & $10(-)$ & $1(t)$ & 生 & \\
\hline
\end{tabular}

静脈接種 $\begin{cases}\text { 死菌 } & 3 \text { 回 } \times 8 \text { 週 } \\ \text { 生菌 } & 1 \sim 2 \text { 回 } \times 8 \text { 週 }\end{cases}$

目 4 Crytococcus neoformans No. 2575 株感染ウサ ギ (No.11) に招ける抗体価の消長

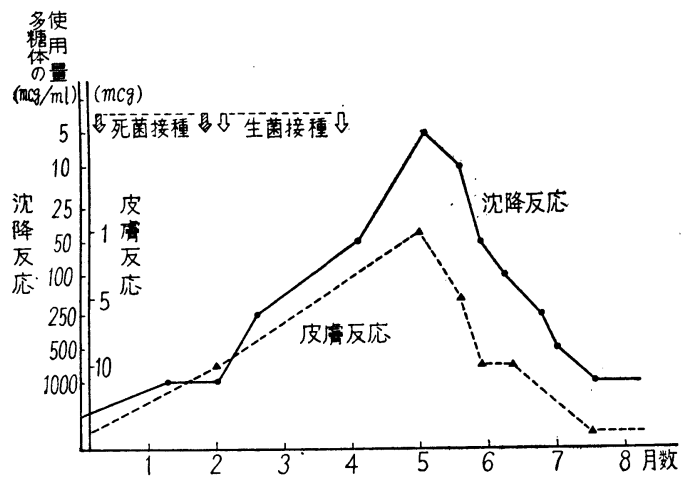

図 5 Cryplococcus neoformans No. 2617株感染ウ サギ（No. 6) における抗体価の消長

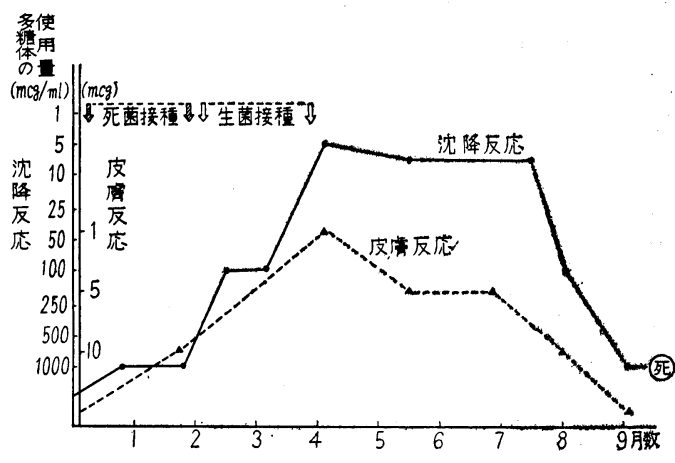




\section{1. 感染ウサギにおける免疫反応の消長}

\#2617及び2575株を感染させたウサギ 6 匹中 4 匹は 4.5〜10月後に死亡した（表 2 ).との 4 匹の剖檢所見と

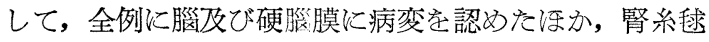
体の炎症 ( 2 匹) 肺の病変 ( 3 匹), 脾の縮小 ( 3 匹), 等 丸炎 ( 2 匹), 紅彩炎 ( 2 匹) なぞ全身感染の狀態が見ら れた。

免疫反憵の経過は圖 4 に示したような而過生存例にお いては，接種開始後 1〜2ケ月後に反應陽性となり，5 ケ月後に最高値に達し, その像は兩反應とも平行して減 弱し 8〜9ケ月後に陰性となつた. 圖 5 は死亡例である が, 兩反雇とも 4 月後に最高に達し, 7 ケ月以後低下し てきたので耐過すると思われたが10ケ月目に死んだもの である。

以上の経過が示すように, C. neoformans 感染の場合 は，頻包の菌の接種にもかかわらずかなり長い潜伏期の 後に抗体が産生されてくるのであつて, カンジダやアス ペルギルス感染のように 1 ～週間で抗体産生を見るも のとは，著しく異るとしろである。

\#2617及び2575株感染ウサギに扝ける最高の抗体俩注 一括して表 2 亿示したが, 沈降価は 5 〜 50 / / c 陽性, 皮内反応は 1 陽性であつて, この值はカンジダやアス ペルギルス感染の場合とさしたる相違はない，従つてク リプトコックス症か亜急性乃至慢性の経過安こるにして
も，免疫反応による診断の可能性脑あるものと思われ 子.

\section{2. 大莢膜株と小萊膜株との抗原の異同}

前述の Evans の研究によると, 免度学的にA，B， $\mathrm{C}$ の 3 型あるとしても， 3 型抗血清間にはかなりの交叉 反応がある点から，さして考慮导払汸なくこもよいよう 飞思われるが, その研究に执いては莢膜の大小の差につ いては考㭸が払われていない。

わが國で分離された株の多くのものは大きい荻膜孛も つものであるが, 東大田坂内科分離株や順天堂村上内科 分離株のように小荻膜型のものもある.よつて, 大型株 と小型株との間に抗原の相異があるか否かを調べて見 た.

表3に示したように, 凝集反應では田坂株と\#2617株 との間にかなりの相異が認められたが，乙れに反して\# 2617からとつた多糖体を抗原として, 田坂株感染ウサギ について抢てなつた沈降反隹と皮内反應とは\#2617株感 染ウサギょりもむしろ強い反㶐が見られた．このとと は，多糖体分劃は兩株に共通であるととを示し，大荻膜 株菌体多糖体流小荻膜株感染に対する抗原としても使用 し得るととを示唆する所見であろう。

次に形態学的汇近似している Candda 及び Saccharomyces との間の交叉反㗹の有無孛, 沈降反應によつて調 べて見た。結果注 4 亿示してあるが，Cryptococcus.多 糖体は Candida 及び Saccharomyces 免疫血清に対して

表 3 大萊膜株

\begin{tabular}{|c|c|c|c|c|c|c|}
\hline \multirow[b]{3}{*}{ 抗血清 } & \multirow{3}{*}{$\begin{array}{c}\text { 沈降反応 } \\
\text { \#2617多糖体 } \\
(\gamma / c c)\end{array}$} & \multirow{3}{*}{ 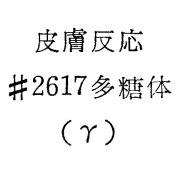 } & \multicolumn{2}{|c|}{ 凝 } & 反 & 応 \\
\hline & & & \multicolumn{2}{|c|}{$\# 2617$} & \multirow{2}{*}{ 田坂 } & \multirow{2}{*}{ 順天堂 } \\
\hline & & & 有萊膜菌体 & 除萊膜菌体 & & \\
\hline $\begin{array}{l}\text { 抗2617血清 } \\
\text { (大萊膜株) }\end{array}$ & $25(+)$ & $1(+)$ & $2 \times(+)$ & $16 \times(+)$ & $2 \times(-)$ & $2 \times(-)$ \\
\hline $\begin{array}{l}\text { 抗田坂血清 } \\
\text { (小萊膜株) }\end{array}$ & $5(+)$ & $1(+)$ & $4 \times(-)$ & $16 \times(+)$ & $256 \times(+)$ & $64 \times(+)$ \\
\hline
\end{tabular}

表 4 Cryptococcus neoformans 多糖体の非特買性

\begin{tabular}{|c|c|c|}
\hline 抗血清 抗原 & $\begin{array}{c}\text { Cr. neof. } \\
\text { \#2617多糖体 }(\mathrm{mcg} / \mathrm{cc})\end{array}$ & $\begin{array}{c}\text { C. albicans } \\
\text { \#2多精体 }(\mathrm{mcg} / \mathrm{cc})\end{array}$ \\
\hline Cr. neoformans 免疫血清 & $5(+)$ & $1000(-)$ \\
\hline Candida albicans 免疫血清 & $1000(+)$ & $1(+)$ \\
\hline $\begin{array}{c}\text { Candida krusei 免疫血清 } \\
(\text { Agg. } 1280 \times)\end{array}$ & $1000(+)$ & \\
\hline $\begin{array}{l}\text { Saccharomyces cerevisiae } \\
\text { 免疫血清 }(\text { Agg. } 640 \times)\end{array}$ & 1000 (十) & \\
\hline
\end{tabular}


極て弱い交叉反應学示すにすぎなかた。

以上の知見から推定してクリプトコックス症の免疫学 的診断用抗原として, 多糖体が使用しうるであるうと考 えられるのであるが, 現在までのとてろ臨床例について 試みる機会学得ていない.

非感染者について非特異反應を試及た知見はつぎのよ らである。

\section{イ. 皮内反應}

\begin{tabular}{|c|c|c|c|c|c|}
\hline \multirow[t]{2}{*}{ 接種量 } & 人員 & + & \pm & - & 備 \\
\hline & ^. 16 & 0 & 0 & 16 & 健康者 \\
\hline \multirow{3}{*}{$1 \gamma$} & ㅁ. 92 & 0 & 2 & 90 & \multirow{6}{*}{$\begin{array}{l}\text { 精神病患者 } \\
\text { 泌层器科来 } \\
\text { 口反応陽性者 } \\
\text { パラリーゼ }\end{array}$} \\
\hline & ․ 8 & 0 & 0 & 8 & \\
\hline & $=.30$ & 0 & 0 & 30 & \\
\hline $2 \gamma$ & ㅁ. 92 & 0 & 2 & 90 & \\
\hline & 八. & 1 & 2 & 5 & \\
\hline & $=30$ & 6 & 6 & 18 & \\
\hline
\end{tabular}

口. 沈降反灾

\begin{tabular}{|c|c|c|c|c|}
\hline & 例数 & 抗原 & + & - \\
\hline & & $1000 \mathrm{r} / \mathrm{cc}$ & 4 & 8 \\
\hline ワ 反応陰性群 & 84 & $\{500 \mathrm{r} / \mathrm{cc}$ & 0 & 8 \\
\hline & & $1000 \gamma / \mathrm{cc}$ & 2 & \\
\hline 反応陽性群 & 8 & $500 \gamma / \mathrm{cc}$ & 0 & \\
\hline
\end{tabular}

（東大附属病院血清検査室分与血清）

以上の成績から, 皮内反應に掞いては多糖体抗原 1 $2 \gamma$ 接種によつて陽性となる場合, また沈降反應におい ては 500 $/ \mathrm{ml}$ 以下の濃度に掞いて陽性となる場合に㧤 いては,クリプトコックス症の特異反良と推定してょい であるうと考えられる. 本章に関する詳細は梁井の原 著到学照されたい。

\section{結 論}

Aspergillus fumigatus 及び Cryptococcus neoformans を以て感染させたウサギについて, それぞれの菌体から 抽出した多糖体分劃安抗原として皮内反礁と沈降反礁を 試及た。

A. fumigatus 感染ウサギに捛いては抗体の産生が比 較的速かであり, 危疫反篧は陽性となつた. 気管支・肺 アスペルギルス症患者 4 例について, 培養壀液 ( 1 例), 菌体磨碎液 ( 1 例), 多糖体 ( 2 例) を抗原として行つた 結果から泳, 深在性アスペルギルス症の免疫学的診断法 は可能であるうと考えられる.
C. neoformans 感染ウサギにおいては, 抗体の産生が 極て徐々で日数要要するが, 皮内反應及び沈降反碓に対 する抗体價はかなり高い值に達した。いまだ臨床例に試 みた成績はないが, 動物実驗の結果からは, 深在性クリ プトコックス症の免疫学的診断は可能であろうと推定さ れる。

附記 本報告は昭和 34 年 10 月 30 日名古屋に扰いて開か れた第 3 回日本医真菌学会に括けるシンポジウムに括い て発表したものである. 協同研究者岩田, 和田, 梁井氏 らの協力に対して謝意を表する。

\section{文献}

1) 秋葉編：菌交代症，医学書院，昭33年.

2) T. Akiba et al.: Jap. J. Microbiol., 1 (1), 11, 1957.

3) Drake, C.H.: Mycopathologia, 4, 103, 1948.

4) Stanley, N.F.: Austral. J. Exper. Biol. Med. Sc., 28, 99, 1950.

5) 川上, 大久保ら：呼吸器診療, 12 (8), 664, 昭 32.

6) 瀬尾: 第 2 回医真菌学会総会, 1958.

7) Henrici, A.T.: J. Immunol., 36, 319, 1939.

8) 古島, 岩田, 和田, 梁井: 胸部外科, 12 (6), 482 , 昭34.

9) Berghausen, O.: Ann. Int. Med., 1, 235, 1927.

10) Kessel, J.F. \& Holtzwart, F.: Amer. J. Trop. Med., 15, 467, 1935.

11) Benham, R.W.: J. Infect. Dis., 57, 255, 1935.

12) Evans, E.E.: Proc. Soc. Exper. Biol. Med. 71, 644, 1949.

13) Evans, E.E.: J. Immunol., 64, 423, 1950.

14) Evans, E.E \& Kessel, J.F.: J. Immunol., 67, 109, 1951.

15) Evans, E.E \& Theriault, R.J.: J. Bact., 65, $571,1953$.

16) Neill, J.M. et al.: J. Exper. Med., 89, 93., 1949.

17) Neill, J.M. et al.: J. Bact., 59, 263, 1950.

18) Neill, J.M. et al.: Proc. Soc. Exper. Med. Biol., 77, 775, 1951.

19) Hehre, E.J. et al.: J. Biol. Chem., 177, 389, 1949.

20) Stanley, N.F.: Australian J. Exper. Biol. Med. Sc., 27, 409, 1949.

21) 和田微郎：日本細菌学雑誌投稿中.

22) 梁井方策 : 日本細菌学雑誌投稿中.

(昭和 35 年 2 月 2 日受付) 